Melek Saral*

\title{
The Protection of Human Rights in Transitional Tunisia
}

\section{Capacity, Willingness and Capacity-Building}

https://doi.org/10.1515/mwjhr-2019-0005

Published online February 28, 2019

Abstract: This article looks at the human rights protection in transitional postuprising Tunisia, from 2011 to 2017, offering insights into the willingness to both protect human rights and build capacity in Tunisia. It focuses on the establishment of an adequate legal framework in Tunisia, with particular attention being paid to the constitution-making process and, on the establishment, the strengthening of certain institutional capacities, such as the constitutional court and the Truth and Dignity Commission. The article first gives a brief historical overview of the human rights situation in Tunisia. This is followed by an analysis of the willingness and capacity to protect human rights in post-uprising transitional Tunisia, in both the 2011-2014 and 2014-2017 periods.This article is based on evidence from a series of semi-structured interviews I conducted with the key political actors from various political parties, and actors from NGOs working on human rights, during field research in Tunisia in October-November 2017, supplemented by secondary literature.

Keywords: human rights, MENA, capacity building, uprisings

\section{Introduction}

The popular uprising in Tunisia, which started in December 2010 and spread across the Middle East and North African (MENA) region, was mainly driven by the failure of the state to respect, protect and ensure human rights ${ }^{1}$

1 This article takes the International Bill of Human Rights consisting of the Universal Declaration of Human Rights, the International Covenant on Civil and Political Rights and the International Covenant on Economic, Social and Cultural Rights as the source of international human rights standards.

*Corresponding author: Melek Saral, School of Law, SOAS University of London, London, United Kingdom of Great Britain and Northern Ireland, E-mail: ms166@soas.ac.uk

Ә Open Access. (C) 2019 Saral, published by De Gruyter. (c) BY-NC-ND This work is licensed under the Creative Commons Attribution-NonCommercial-NoDerivatives 4.0 License. 
(Richardson-Little 2015, 158). In reaction to years of systematic human rights violations, protestors employed the language of international human rights and demanded "freedom of expression", "democracy" and the application of "human rights" (Monshipouri 2014, 63-64), challenging the existing authoritarian arrangement (Mokhtari 2015) and ousting the long-standing repressive Ben Ali government. These events have not only proved to political actors that human rights and freedoms are an articulation of human nature rather than artificial state constructions (Hamd 2016, 1-2), but have also raised hopes for the improvement of human rights in the country. Human rights have become a more frequent topic of discourse as political actors have repeatedly referred to them to claim legitimate authority and popular support (Odysseos and Selmeczi 2015, 1033-1035), regardless of their political background or former positions on the issue.

Tunisia is most commonly described as the rare success story of the socalled Arab Spring and is considered to be the country influenced most positively by the uprisings (Badria 2016, 567; Yerkes 2018). Although Tunisia's eightyear-long transition has faced numerous challenges and obstacles, such as terrorist attacks, economic crises, political deadlock and conflict between secularists and Islamists, its legal and political systems have seen extreme changes during this period (Yerkes 2018). The country has experienced a comparatively successful transition process, with strengthened civil rights and fundamental freedoms, flourishing activist movements and relatively stable political institutions. Two years after the uprisings, Freedom House upgraded Tunisia's status from "Not Free" to "Partly Free" because of its significantly improved human rights record (Freedom House 2013). Two years later, Freedom House designated Tunisia as the only free country in the region due to its adoption of a progressive constitution, improvements in governance, and the holding of free and fair parliamentary and presidential elections (Freedom House 2015). Reports published by Human Rights Watch after the uprisings have also praised the country's flourishing human rights record (Human Rights Watch 2015, 2016a, 2017).

The positive outcome of a democratic transition, with regard to the protection of human rights, is conditioned by a combination of several domestic and international factors, including regime type, legal structure, an independent judiciary and a vibrant civil society (Landman 2005). Tunisia's comparatively successful transitional process is mostly explained by its historical and cultural background, highly educated population, a large middle class, weak military, vibrant civil society, low strategic importance, and homogenous population. The capacity and willingness of a state are also regarded as significant key determinants for the improvement of human rights in a transitional country. 


\section{Capacity, Willingness and Human Rights Protection}

Thomas Risse points out that many transitional countries on a path to democratization have committed themselves to international human rights, but human rights are nevertheless violated because institutional capacity is lacking. He underlines the significance of a state's institutional capacity to protect human rights and claims that in most cases violations of human rights are not due to a lack of willingness but of capacity (Risse 2018, 139). Indeed, institutional capacities are needed to both protect human rights and translate human rights demands from the streets into decision-making processes (Hamd 2016, 3-4). However, the willingness of political actors to improve human rights should not be taken for granted considering that commitments in this regard might be extremely costly. Moreover, for human rights protections to be effective, both institutional capacity and willingness are necessary (Anaya-Munoz and Murdie 2018). In fact, for transitional countries like Tunisia, willingness is a more vital condition as it also determines the country's capacity to build effective human rights protections. Tunisia made remarkably effective efforts in establishing democratic institutions in the first three years following the uprisings. However, after seven years of revolution there are serious signs of a slowdown in the democratic transition process and a setback in the form of a lack of willingness both to protect human rights and, more importantly, to build the necessary capacity. In some cases, even the effectively established institutions have been hindered or slowed down by political actors.

State capacity is defined based on the notion of ability, and refers to the material and human resources of a state giving it the ability to make, implement and enforce rules and regulations (Acemoglu, Garcia-Jimeno, and Robinson 2015; Anaya-Munoz and Murdie 2018, 8-9). Capacity building in the field of human rights mostly refers to the establishment of an adequate legal framework and the establishment and strengthening of institutional capacities and civil society. These three elements are key to the protection and enforcement of human rights. Compared to capacity and capacity building, willingness is more challenging to conceptualise as it is mostly taken for granted and not explicitly studied in the human rights literature. For the sake of this paper, willingness refers to the preference and intent to achieve a given outcome, and to act accordingly (Post, Raile, and Rile 2010; Anaya-Munoz and Murdie 2018, 9). It includes the preference and intent to build the needed capacity for the protection of human rights such as a legal framework, institutional capacities, and civil society. Willingness in the political actors can also be observed by their statements in addition to their behaviour. Often statements of political actors can be rhetorical or tactical concessions driven by strategic calculations (Anaya-Munoz and Murdie 2018). Thus, it 
is significant when signals given by the actors regarding human rights protections relate to costly commitments or a consensus which has some serious effect on political interests and longstanding ideologies.

This article looks at the human rights protection in transitional postuprising Tunisia, from 2011 to 2017, offering insights into the willingness to both protect human rights and build capacity in Tunisia. It focuses on the establishment of an adequate legal framework in Tunisia, with particular attention being paid to the constitution-making process and, on the establishment, the strengthening of certain institutional capacities, such as the constitutional court and the Truth and Dignity Commission. The paper illustrates that during the uprisings, from 2011 to 2014, despite the extraordinary challenges in transitional Tunisia, the willingness to protect human rights and create the necessary legal and institutional frameworks for the protection of human rights was high. This was also mirrored in the positive reports published by the human rights organisations, and in the extraordinary levels of readiness of various political actors to reach a consensus on controversial issues, such as the place of religion in the country's legal and political system. This period has also been described by many Tunisians as a period of extreme freedoms and liberties. ${ }^{2}$ However, the period starting in 2014 shows signs of a serious decline in willingness and capacity building to safeguard human rights. Since 2014, the Tunisian government has failed in the establishment of the institutions necessary to effectively protect human rights, which in turn has negatively affected the human rights situation in the country. The return of many faces from the old regime to the political scene with the victory of Nidaa Tounes in the 2014 elections was one of the main reasons why the government has shown less interest in capacity building. Moreover, the ongoing and growing economic instability has also restricted the government's ability to establish institutions needed for the protection of human rights, and security concerns have given rise to legal and institutional measures impacting human rights negatively.

The article first gives a brief historical overview of the human rights situation in Tunisia. This is followed by an analysis of the willingness and capacity to protect human rights in post-uprising transitional Tunisia, in both the 2011-2014 and 2014-2017 periods. As Ennahda became the most important force in Tunisian politics after the uprisings, this paper pays special attention to their position and action on human rights and capacity building issues during the initial 2011-2014 time period, particularly with regard to constitution-making.

2 Interviews conducted in November 2017 with constitutional law professor Said Kais, Youth Can president Zyna Mejri, and Ennahda deputy Mahrezia Labidi. 
The focus of the second period, 2014-2017, is more on the efforts of government officials to block and/or establish the legal and institutional capacities to protect human rights. This article is based on evidence from a series of semi-structured interviews I conducted with the key political actors from various political parties, including: Ennahda, Nidaa Tounes; the Popular Front; and actors from NGOs working on human rights, such as Albawsala, I Watch and Youth Can, during field research in Tunisia in October-November 2017, supplemented by secondary literature.

\section{Human Rights in Tunisia during Bourgouiba and Ben Ali Era}

Tunisia became a sovereign state in 1956 after a short war of independence against France. After gaining independence the country was briefly ruled by a king, before he was replaced by the first elected president Habib Bourguiba, leader of the nationalist Neo-Dustur party (Entelis 2007, 520). Bourguiba ruled the country for 31 years and turned the country towards the west, enacting several reforms to create a secular and modern country. These included restructuring the Tunisian court system under a secular model, reforming the personal status law legalizing divorce, authorizing abortion, giving free access to contraception, prohibiting polygamy, setting a minimum age for marriage and controlling Islamic institutions such as the Zaytuna Mosque (Borg 2017; Andrieu 2016, 265). Bourguiba's policies to modernise the country by controlling religion entailed the violation of religious freedoms. Many of his modernisation policies took aim at religious practices and included raising objections to the Ramadan feast on the basis of cost and fighting against the veiling of women. In fact, Bourgouiba was an authoritarian and repressive ruler and during his presidency, increasing repression of human rights and freedoms was accompanied by growing political opposition. Opposition movements, including leftists and Islamists, suffered human rights violations during Bourguibas' presidency. In the 1970s the leftist opposition was a victim of Bourgouibas' authoritarian rule. During this period leftist student movements and labour unions were almost completely dismantled. In the 1980s the Movement of the Islamist Tendency (MTI) - founded in 1981 by Rached Ghannouchi and changing its name to Ennahda in 1989 - was the government's main target and many of its activists were arrested and tortured, including the MIT president and founder (Andrieu 2016, 266; Willis 2012: 164-166).

Bourguiba was removed from power in 1987 through a bloodless coup instigated by prime minister Zine el Abidine Ben Ali. When Ben Ali seized 
power, he declared human rights to be the fundamental duty of his government (Graenzer 1999, 126), and stated that the purpose of his succession was to preserve and expand Tunisian human rights. He masterfully applied human rights discourses to justify the coup (Graenzer 1999, 126). However, during his regime, the country was ruled by a centralized state power in an unaccountable presidential system with a weak parliament and judiciary. Constitutional guarantees of human rights existed but lacked the support of strong institutional guarantees (Johnson 2015, 1049-1050).

In the first years of his rule the country experienced relative political liberalisation and formerly-suppressed elites and civil society groups including international organisations experienced an era of freedom ${ }^{3}$ (Graenzer 1999, 126-132; Mednicoff 2003, 86). He also legalised Ennahda and allowed the party to participate in the 1989 elections. Several international treaties ${ }^{4}$ were also signed and ratified, and thousands of political prisoners were granted amnesties. However, this so-called era of liberalisation was in fact a series of limited, tactical concessions that lasted only until Ben Ali had consolidated his power and Islamist activism had been revived and started to threaten secular Arab politics in Tunisia. After that, Ben Ali turned Tunisia into a police state, fiercely violating the rights of the Tunisian people. He introduced political and legal measures to restrict the activities of national human rights groups and put limits on the freedoms of the press, association, and information (Andrieu 2016, 266; Anderson 2011; El-Khawas 2012, 2-3). In the 1990s, the targets of his repressive rule were mainly Islamists and Ennahda, which had been banned and its members imprisoned, tortured or forced into exile. However, other opponents or independent elements of civil society including human rights activists were also victims of human rights violations including restrictions on their freedom of expression, torture and arbitrary execution (Andrieu 2016, 267; Murphy 2012, 2-5). The Tunisian League of Human Rights (LTDH), which upon its establishment in 1977 was the first significant indigenous human rights organisation in the region, dissolved itself in 1992 in reaction to Ben Ali's repressive politics ${ }^{5}$ (Mednicof 2003, 87). LTDH Secretary General Khemais Chammari was arrested in 1995 together with the leader of the Movement of Social Democrats

3 For instance, Amnesty International was permitted as a legitimate organisation.

4 Including the Convention against Torture (CAT), the Convention on the Elimination of all forms of Discrimination Against Women (CEDAW), and the Convention on the Rights of the Child (CRC)

5 LTDH was re-founded in 1994 but with an agenda closely conforming to the government position. 
because of a letter addressed to Ben Ali complaining about the restrictive politics of the government (El-Khawas 2012: 2-5). The war on terror after 9/11 also helped the Tunisian police state justify or conceal severe human rights violations (Andrieu 2016, 267).

Human rights violations have been routine in Tunisia since independence; however, at the same time the language of rights has also long been important to Tunisian political discourse (Borg 2017). Both leaders, Bourgouiba and Ben Ali, tried to maintain the image of Tunisia as a secular and modern country. They continued to control human rights discourse, but at the same time repressed all forms of political competition, critical media and human rights activism in the country (Huellen 2013). Tunisia was particularly praised by the international community as an example with regard to its progressive women's rights in contrast to other Muslim countries in the region. However, the authoritarian regimes in Tunisia supported only the rights of secular and well-educated women and allowed only state-monopolized discourses of women's rights (in other words, state feminism) whereas independent feminist women's organisations were suppressed (Borg 2017). For western countries Tunisia was a reliable partner and a safeguard against Islamist movements. Thus, no coercive measures or sanctions were taken against Tunisia although international human rights law norms relating to civil and political rights were frequently denied to its citizens (Huellen van 2013).

\section{Arab Uprisings and Human Rights in Tunisia}

The Tunisian revolution, which started on December 17, 2010 and spread to other countries in the region, led to regime change on January 14, 2011. Tunisia has subsequently experienced years of significant political and institutional change. Compared to uprisings in other countries in the region, Tunisia was more successful in forming effective parties, holding competitive elections, and establishing other institutions necessary for democratic transition (Bellin 2011, 6), as it has more favourable conditions for democratic transition including high levels of literacy, a large middle class, an ethnically and religiously homogeneous population, a small and politically inactive military, and a vibrant civil society. In particular, the rapidly flourishing civil society in the post-uprisings era played an important role in the success of transition by monitoring the government and protecting human rights. The best known achievement of the civil society organisations contributing to the success of the transition was the role of the National Quartet in brokering a 
compromise between secularists and Islamists, which was awarded the Nobel Peace Prize in 2015 (Yerkes 2018). Many other CSOs have played important roles in the positive development of human rights in Tunisia, such as: AlBawsala monitoring the activity of the National Constituent Assembly (NCA) and informing the public about its activities; I Watch monitoring the government on administrative and financial corruption; and Manish Masameh (I shall not forgive) lobbying the public against the economic reconciliation giving amnesty to former regime officials involved in major corruption cases (Chakroun 2018; El’Manai 2018).

Following the uprisings, Tunisia was able to take several effective steps to build capacity and to make the necessary changes in its legal and institutional frameworks to protect human rights. The most important steps in this regard were the adoption of the 2014 Constitution, the establishment of independent commissions - including the Truth and Dignity Commission, the Commission against Torture, and the Human Rights Commission - and the approval of bills which, for example, guaranteed the right to access information and fight violence against women. The establishment of these institutions provided the country with the basic necessary capacity to protect human rights, and a high degree of willingness together with this new institutional capacity gave rise to a flourishing human rights records in the country. As a result, the post-revolution era has not only put human rights at the centre of the country's continuous struggle for a democratic transition but also provided Tunisian citizens with liberties and freedoms which had been denied to them by authoritarian regimes before the uprisings (Human Rights Watch 2015, 2016a). Certainly, there are still serious challenges to the protection of human rights present in the country, which have been carried over from the previous regimes. In particular, human rights violations like torture, and mistreatment by the security forces still continue. However, the main difference in the post-uprisings Tunisia is that these violations are not institutionalised, as during the previous regime.

Human rights activist and Constituent Assembly Member Fadhel Moussa described the dramatic improvement in human rights after the uprisings with the following words:

The people expressed their desire to change the political situation in our country, especially the human rights situation including civil, political, economic, social, and cultural rights as stipulated in two international conventions of human rights. We can say that Tunisians experienced a huge improvement in their civil and political rights, and Tunisia is today a democratic country with regard to human rights criteria. ${ }^{6}$

6 Interview conducted with Fadhel Moussa in November 2017. 


\section{Huge Popularity of Human Rights Issues after the Uprisings}

One of the key gains during the transitional period in Tunisia was that human rights became hugely popular after the uprisings. Human rights became the number one political and social topic in the country and post-uprising Tunisia experienced an extensive use of rights discourse, regardless of ideology or religious differences (Borg 2017, 455; Stephens and Callaway 2014, 426). Political actors, irrespective of their political background, conveyed their willingness and readiness to protect human rights in the country. Although, these statements alone cannot be taken as evidence of their willingness to protect human rights, they give some indication in this regard, particularly if these statements were about politically or ideologically sensitive issues which might have costly consequences. Moreover, these statements influenced Tunisian understandings of human rights and they raised awareness of the issues, affecting how human rights advocacy and enforcement strategies were subsequently designed (Hamd 2016).

The executive director of Al-bawsala ${ }^{7}$ (a non-profit non-governmental organisation established under Tunisian law) Selim Kharrat described this atmosphere of popular support for human rights in post-uprising Tunisia with the following words:

The most important change is related to the general mind-set of the political elite and public opinion concerning human rights. Human rights just after the 2011 uprisings became the main topic of political debate. Every political party is ensuring that they respect human rights. ${ }^{8}$

The atmosphere of the post-revolution era undeniably forced political actors to legitimise themselves by making statements about the protection of human rights. In some cases, this meant that they had to tackle issues which are not in line with their ideological background or political interests. This behaviour in particular provides an excellent insight into the willingness of political actors to protect human rights, as these are mostly in areas which carry some political costs. In this context, looking at the statements of one of the most significant key actors in post-uprising Tunisia, namely Ennahda, is helpful in illustrating their willingness to protect human rights. It should be emphasised that the political behaviour of Islamist parties and their statements has

7 The organisation is independent of political influence and monitors legislative and executive proceedings, advocates for fundamental rights and individual freedoms, and assists in the development of citizens' initiatives (https://www.albawsala.com/en/presentation).

8 Interview conducted with Selim Kharrat in November 2017. 
been one of the most significant determinants of how post-uprising transitions have evolved in the MENA region. Several Islamist parties, such as Ennahda in Tunisia and the Freedom and Justice Party in Egypt, became central actors with majority seats in parliament, and faced great challenges including the need to rethink their ideologies and strategies, and the question of how to handle peoples' expectations after the uprisings (Guazzone 2013, 30). Ennahda's electoral victory and its presence in the political scene after the revolution caused deep concerns and fears of Islamization, which might in turn also negatively affect human rights in the country. These concerns were increased by Ennahda's attempt to position Sharia in the constitution as a source of legislation as well as by the controversial speeches of Ennahda parliament members, such as Sadiq Shurus, who called for freedoms, which might be used to justify the insult of Islam, to be restricted (Elin 2013). However, it should be emphasised that Ennahda is not a homogenous movement. Although the movement includes more radical members who resemble Salafists, one can say that Ennahda has a moderate political ideology. Its leaders, especially Ghannouchi, have been at the forefront of Islamic thinkers who are progressively bridging the idea of an Islamic state with the requirements of democratic processes, particularly by linking individual and group rights to the concept of citizenship rather than religious membership. Ennahda's 2011 electoral program also stated the need to establish a 'civilian state' (dawla madaniyya), which is "responsible for the respect of public and individual liberties" (Guazzone 2013, 44-45; Pickard 2011: 644). Furthermore, at the tenth congress of the party in 2016, its political and religious activities were separated and "political Islam" was left behind in favour of embracing "Muslim democracy” (Feuer 2016).

With regard to human rights, post-uprising Tunisia faced an intense debate between Islamists and secularists over the universality and cultural relativity of rights, concerning whether they were consistent with cultural and religious beliefs and practice in the country. As already mentioned there were widespread fears that a religious interpretation of human rights would move Tunisia away from universal human rights and push the country towards a culturally relativist approach. However, in spite of these conflicting diverse interests, political actors - with the help of civil society - were able to reach a consensus and showed willingness to contribute to the improvement of human rights in the country. This was confirmed by former Tunisian President Moncef Marzouki, who described the readiness of the various political actors to engage with human rights issues with the following words: 
With regard to human rights, we had the same will to abolish torture - don't forget that Ennahda [members] were the main victims of torture. I had three prime ministers and all of them were extremely interested and committed to this way of thinking; I did not have any problems in this regard. None of them would tell me, 'Mr President, we have had terrorist attacks so forget about torture. Nobody said something like that.'

\section{Concessions and Consensus for Successful Constitution-Making}

One of the most important steps with regard to the establishment of the legal framework as part of the necessary capacity building in Tunisia has been the constitution-making process. The constitution-making process in Tunisia has reflected the diverse approaches of various parties to the critical questions of how to guarantee the basic rights of Tunisians violated by the former regime. The process has been marked by the constant search by all parties for consensus, which makes the Tunisian experience distinct from other Arab uprising countries. During this period, Ennahda has also shown a higher degree of readiness to make concessions in the interest of consensus (Pickard 2015, 4-5; Rainer et al. 2016: 911). It has constantly made significant concessions on previously accepted ideologies, such as deciding to exclude a provision for Sharia as the sole source of legislation in the draft constitution; accepting the straightforward references to "equality" in the Article about the status of women; or granting the right to freedom of conscience and belief (Netterstrom 2015; Marks 2014; Guazzone 2013, 38-39).

Ghannouchi regards consensus as the main reason for the success of the Tunisian transition, which he emphasized when he said, "The Tunisian magic formula is consensus. Nothing goes forward without consensus between the different sides, between the opposition and coalition government and between the different parties." 10 Ennahda showed effort in reaching consensus, even on issues not in line with previously accepted ideologies, which gave way to a smoother transition in Tunisia compared to other countries. As Ghannouchi puts it:

We have discovered that in periods of transition what you need is not a simple majoritarian democracy but a consensus based on democracy, where you take everyone with you in forming the constitution, in shaping the future of the country ... .Ennahda has given a lot of concessions to avoid this polarization ... [including on] the issue of Sharia: the mentioning of Sharia in the constitution was one of the things that could have divided our society.

9 Interview conducted with Moncef Marzouki in November 2017.

10 Interview with Rached Ghannouchi conducted in November 2017. 
That is why we decided to leave it out of the constitution. The constitution in the end was passed by 97 percent of the parliament. ${ }^{11}$

The constitution-making process has been highly significant during the postuprising era, providing an atmosphere of constructive debate of human rights, and giving interesting insights into the positions of Islamists and secularists on human rights in the context of the new constitution. The constitution-making process was dominated by a struggle between Islamic political groups - mainly Ennahda members - and secular movements - mainly members of the Congress for the Republic and Ettakatol - to prioritise their interests and ideologies (Rainer et al. 2016: 911-912). One of the interviewees described the process as "a war over the definition of terms". ${ }^{12}$ The process lasted three years during which three drafts were submitted to the National Constituent Assembly. Each of these drafts was the subject of debates and amendments. After the first draft was presented in August 2012, a second draft followed on December 14, 2012 and the third draft on April 25, 2013. The drafting process was interrupted by the assassination of the secular opposition leader, Shoukri Belaid, on February 6, 2013 (Sadek 2013: 1). Finally, the new constitution was adopted by the National Constituent Assembly on January 26, 2014, containing provisions which broadly incorporate international human rights law norms and was accepted by both secular and Islamist actors. The debates on freedoms and liberties during this constitution-making process are illustrated by Ennahda deputy Imen ben Muhammed:

The constitution includes very clear and very detailed articles about freedom and liberties. When we discussed the chapter on freedom and liberties in the Constituent Assembly many members of parliament said we maybe should name that part "Freedom and Citizens' Obligations", but the majority wanted to name it "Freedom and Liberties", because what we lacked before the revolution was our freedom and liberties. And we had a long discussion about the extent of the details. Should we have a general constitution that makes a general reference to freedom and liberties, or a constitution containing more detail about different freedoms and liberties? In the end we agreed that we should include all the details ... and we included the famous Article 46 stating that there are no limits to any kind of freedom or liberties by law.

During the process of drafting the new Tunisian Constitution, there was considerable debate between Islamist and secular movements about the role of Islamic law in the constitution (Sadek 2013). Because of the overwhelmingly negative state of human rights in the MENA region, a common question is whether the violation of human rights is due to the predominance of the Islamic religion and several studies

11 Ibid.

12 Interview with Fadhel Moussa in November 2017. 
have been conducted to explore the compatibility of human rights and Islam (Monshipouri 1998; Mayer 2013; Sachedina 2009; Baderin 2005; Bielefeldt 2000; Chase and Hamzawy 2006). In spite of the immense diversity of cultural, social and political frameworks, as well as the different interpretations of Islamic thought across the Middle East, one can hardly deny that religion significantly impacts human rights legislation and practice in Muslim countries, and Tunisia is not an exception in this regard. Although Tunisia has the most progressive women's rights in the region, its family and personal status law partially rely on Sharia law. The practice and legislation of inheritance law, for instance, is still based on Sharia law. However, Tunisia also has a very progressive interpretation of religion and an influential political and religious figure, Ghannouschi, who underlines the compatibility of Islam with democracy and human rights (Pickard 2011: 644).

In this context, any references to religion or Sharia in the constitutions of Muslim-majority states are also important to consider. Today many constitutions in countries with predominantly Muslim populations make some reference to Islam. This is illustrated, generally, either in the preamble, or in the form of the determination of a state religion, the principle that legislation conforms to the principles of the religion, or conditions to be met by the head of the state. Many constitutions also limit the scope of certain rights and freedoms out of respect for Sharia (Dupret 2016, 238-239). During the constitution-making process in Tunisia, debates and conflict also mostly centred on the question of religion and the place of religion in the constitution. Debates about whether Sharia law should be mentioned in the constitution marked the first years of the constitution-making process. An internal Ennahda draft text stated that Sharia law would be a "source among sources" of legislation. However, after the leftleaning Ettakatol party threatened to withdraw its support from Ennahda's governing coalition and to bring down Jebali's government if Sharia law was referenced in the constitution, Ennahda backed down and the August $2012 \mathrm{draft}$ of the constitution contained no reference to Sharia (Darin 2015, 1031). The final draft of the constitution was the product of a consensus which differed broadly from the first draft, as described by leftist Popular Front MP Chafik Ayadi:

There is the pre-Brahmi Association constitution and the post-Brahmi Association constitution. When you go back to the first constitution you can see it has nothing to do with the current constitution in relation to established human rights. In the first one, you see a constitution - we can say without exaggeration - that establishes a religious society. It has nothing to do with international human rights, whereas the second one guarantees the coexistence of all Tunisians whether they are Islamist or secularist. ${ }^{13}$

13 Interview conducted with Chafik Ayadi in November 2017. 
To reach this consensus and to establish a constitution which satisfied almost all political actors and enabled Tunisians to live together was a risky step for Ennahda as it touched on deeply sensitive issues within the party. Ms Labidi illustrated this in an interview given in February 2018, giving details of how Ennahda and particularly Ghannouchi took steps during the constitution-making process to made concessions in order to establish the necessary institutional capacities, even risking a crisis within the party:

Conservative and secularists started from two different points, which were also sometimes contradictory and in conflict. The majority of Ennahda MPs wanted the constitution to refer to Islamic principles and values. Yet the other side wanted a reference to human rights in their universality without any cultural or religious exceptions. When this battle between secularists and conservatives was polarised ... Sheikh Ghannouchi ... took a very audacious step; I don't know if he consulted the Shura Assembly of Ennahda before taking it but actually I think he didn't. He made a declaration that was beneficial for Tunisia and for the constitution-making process. He declared that we were not going to mention Sharia or reference Sharia in the constitution, and we would just keep Art 1 of the 1959 Constitution ... as this article contains enough reference to Islam. After making this declaration he called the Shura Assembly to vote on it ... I was concerned that my colleagues in the party might say no. This would provoke a serious crisis in the party, but thankfully a clear majority was in favour of Ghannouchi's declaration. ${ }^{14}$

The final consensus reached has produced two very important articles, Articles 1 and 2, which satisfied both Islamists and secularists. Most of the secular and religious political actors agreed to keep Article 1 of the 1956 Constitution, which explicitly states that "Tunisia is a free, sovereign and independent state, whose religion is Islam" and Article 2 which states that "Tunisia is a civil state, based on citizenship, the will of the people and the rule of law". Islamists regarded Article 1 as sufficient as it describes the religious identity of the country, with no need to insert a special provision declaring Islam the main source of legislation. They also had no objections regarding Article 2. Ghannouchi defended these two articles by saying:

In the constitution we have two things that cannot ever be changed: that Tunisia is a Muslim state, and that it is a civil state. These two things cannot be changed because we do not think they are contradictory. We believe that they can be compatible.

Leftist Fadhel Moussa illustrated the position of the other camp and underlined the importance of these two articles when he said the following:

Let's also remember that 'modernists and secularists' were in the power at that time, in 1959. They accepted Article 1, because they knew the sensibilities of this country and were aware of how strongly the majority of Tunisians were attached to Islam and Arabness ...

14 Interview conducted with Mahrazia Libadi in February 2018. 
For 50 years Tunisia functioned under Article 1 and we maintained it: we had no problems between secular and religious elements in our country. However, this new constitution is better than the previous one in this regard, because we have added Article 2, which ... means that Tunisia is a civil state based on citizenship and not on belief ... The constitution is also based ... on the supremacy of law, not on the supremacy of Sharia. So we can say that we have, in Article 2, an important safeguard. ${ }^{15}$

\section{Readiness to Discuss Controversial and Costly Issues: LGBT Rights}

Ennahda was willing to contribute to the protection of human rights in the country. However, this was a challenging task as the expectations and demands of Tunisian citizens needed to be balanced with the ideological and religious standpoint of the movement. In this regard Ennahda was struggling with challenges posed by wide-ranging liberties in the post-uprising era. On one hand they were expected to address these issues as one of the key political actors in the country. At the same time, they were supposed to consider heterogeneous interests within the party and justify their positions in line with their religious and ideological principles.

The position of Ennahda with regard to LGBT rights is remarkable in this regard. Although I never directly asked any of my interviewees about their position on LGBT rights, they addressed this issue either to demonstrate their high degree of readiness to protect human rights or the progressive stance they took on liberties compared to other actors in the country. The statements on LGBT rights are also important since they have the potential to cause costly political conflict within Ennahda, considering that the movement is not homogenous and includes some radical Islamist members. It should also be underlined that Ennahda does not need to act rhetorically regarding LGBT rights, as this is a taboo issue in the country regardless of the political background of the parties. Relatively progressive statements on LGBT rights such as these by Ennahda members are rarely made in Muslim countries or by other Islamic parties, and they were welcomed by people from different political factions as illustrated in the following statement from an interview with the president of the Youth Can Organisation, Zyna Mejri:

There is something different about the Ennahda party that is not the same as it was in 2011. I mean, they changed a lot, which is a good thing, and despite the fact that I am not a friend of the party, for now I would say that it is the only party adopting values in line with

15 Interview with Fadhel Moussa in November 2017. 
the Tunisian condition. We feel this when the head of the party, as an Islamist party, says that he was in favour of LGBT rights. ${ }^{16}$

Mejri is referring to a media interview in which Ghannouchi stated that the forced anal examination of LGBT people ${ }^{17}$ may be considered part of a person's private life and questioning whether the state or religion must intervene in this. ${ }^{18}$

Along the same lines, Ennahda deputy Mahrezia Labidi addressed the issue of LGBT rights when I asked her about differences between secularist and Islamist actors in Tunisia with regard to the protection of human rights. She used the issue of LGBT rights as an example in support of their progressive stance on human rights, telling the following story:

The French Minister of External Affairs was having lunch with civil society representatives in Tunisia. Among the representatives there was a young man representing homosexual organisations. Each civil society representative of course described the situation in Tunisia and expressed his. This young man spoke about not having equal rights in Tunisia and he asked for more rights and for equal treatment as a Tunisian citizen from a sexual minority. The French minister replied to the young man, 'I understand that you suffer especially due to the opposition of Ennahda, the religious party," and the young man replied we were in fact the most understanding group who did not even want to criminalise them. We are the most progressive on this issue.

In relaying her support of LGBT rights, the Ennahda member also referred to constitutional guarantees for the rights of Tunisian citizens. In this regard we can say that there was a willingness to protect rights by enabling institutional capacity for this purpose. For instance, Ennahda MP, Imen bin Muhammed defended LGBT rights (with the exception of the right to marriage) with the following statement:

When we talk about homosexuality, in my opinion - even though I am from a political party which has a religious inspiration - we cannot discriminate against someone based on their sexual orientation, because rights are guaranteed in the constitution regardless of religion, gender, belief or any other topic. So, we cannot discriminate against someone because of this, but we cannot give them the right to get married - you cannot do this because our act of marriage is based on a religious principle, not a dual system based on civil and religious ceremonies. ${ }^{19}$

16 Inteview conducted with the president of Youth Can, Zyna Mejri in November 2017.

17 Article 230 of Tunisian Panel Code - dating back to French colonial era - criminalises consensual same sex relations with up to three years' imprisonment. People suspected of engaging in same sex relations are forced to undergo anal examinations to conclude if the accused person has engaged in homosexual conduct (Human Rights Watch 2016b).

18 Interview with Selim Kharrat in November 2017.

19 Interview with Ennahda deputy Imen bin Mohammed in November 2017. 


\section{Decline in the Willingness and Capacity Building for Human Rights Protection}

The economic growth problems, political associations and terrorist attacks, and growing fear for the Islamisation of Tunisia threatened to push the transitional process of the country into a major crisis (Quamar 2015, 280). In particular, the failure to address the simple everyday needs like rubbish collection, high unemployment rates and political instability has created an atmosphere of nostalgia for the Ben Ali era. There was a desire for more experienced traditional politicians to lead the country, which made Nidaa Tounes an attractive alternative for the voters. Nidaa Tounes was founded in 2012 by Beji Caid Essebsi, an 88-year-old politician who served both Habib Bourguiba and Ben Ali. It was formed in opposition to Ennahda, drawing from Ben Ali officials, and Ben Aliera parties, and leftist union leaders (Teyeb 2014). Nidaa Tounes won the majority of the seats in the National Constituent Assembly (85 of the 217 seats), followed by Ennahda winning 69 seats, in the 2014 elections, which took place amidst a political crisis and economic challenges. As Nidaa Tounes fell 24 seats short of a simple majority, a grand coalition between Nidaa Tounes, Ennahda and two minor parties (The Free Patriotic Union and the Afek Tounes) was formed (Quamar 2015, 281-282).

Although the coalition has not managed to address many of the Tunisia's challenges, such as poor economic growth, security sector reform, and judicial reform, important steps in addressing the rights of women have been taken during this recent period. For instance, in July 2017 the Tunisian Parliament adopted a comprehensive law addressing violence against women. Following this, in September 2017 the directive prohibiting the marriage of Tunisian women to non-Muslim men was also lifted by the Justice Minister (Human Rights Watch 2018). However, some of the legal steps taken during this period have threatened a backlash regarding capacity building in the field of the legal framework. One of the most controversial issues was in relation to the reconciliation bill, which gave amnesty to officials from the Ben Ali era involved in corruption cases provided they repaid the stolen money. This bill was defended by Nidaa Tounes and Ennahda members as a necessary step to be taken in order to make the country's economy work again by creating funds and recovering billions of dollars. Although the bill was harshly opposed by the civil society and political opponents because it would harm the whole transitional justice process, it was passed in September 2017. The struggle of the Nidaa Tounes to push the bill reinforced the view that the party is a continuation of Ben Ali' $s$ Constitutional 
Democratic Rally (RCD), and led to a decline in the credibility of Ennahda as a partner of a corrupt alliance (Yardımcı-Geyikçi and Tür 2018, 794).

During the grand coalition period, the ongoing security threats continued to challenge the basic rights and freedoms of the Tunisian people. In particular, after the 2015 terrorist attacks, the government of Tunisia started to roll back freedoms. It imposed a state of emergency and passed a counterterrorism law that allows authorities to detain terrorist suspects without charges and a lawyer for 15 days (Fassihian 2018). Moreover, in 2017 the police union lobbied for a bill on the "repression of attacks against the armed forces", which was pulled because of strong domestic and international pressure (Amnesty International 2017). However, the bill returned to the agenda because of the suicide bombing in Avenue Bourguiba in October 2018. Another worrisome development with regard to human rights is the decline in the productive collaborative work between CSOs and the government due to the growing trust gap between the two; particularly worrisome is the CSOs law 30 of 2018, which foresaw the compulsory national registration of institutions, including CSOs (Yerkes 2018). This period is described by Zyna Mejri with the following words:

I would describe the period from 2011 until 2014 as the happy, dreamy period of postrevolution Tunisia. Everyone was dreaming of change, everyone was dreaming of democracy and then from 2014-2017 the real fight started. It was a fight not to gain new rights but to keep our old rights. For instance, when the president proposed a law that gave amnesties to corrupt people who we had been fighting in the 2011 revolution ... After 2014 we realized that we had to keep fighting to protect the rights we had gained, because the elected government or the elected president was trying to turn back the human rights situation in Tunisia ...

As has already been pointed out, one of the most significant problems affecting human rights protection in the country since 2014 has been the failure to establish institutions guaranteed by the constitution and dedicated to the protection of human rights. The government has failed to appoint any members of the constitutional court, which is vital for a functioning human rights regime, and has stopped the work of the Truth and Dignity Commission (IVD). Specifically, the major coalitional partner, Nidaa Tounes disdained the work of the IVD, and attended none of the public hearings held by the commission (Yardımc1-Geyikçi and Özlem 2018, 794). Although some of the constitutional commissions could not be activated because of the lack of financial resources, thus restricting the capability of the state for capacity building and slowing down the establishment of some very necessary institutions such as the constitutional court, the lack of consensual support for the establishment of the constitutional court and for the work of the Truth and Dignity Commission has 
created the suspicion that the Ben Ali era officials were the real cause for this slowdown. Nidaa Tounes is mostly seen as a continuation of the old regime because it inherited not only the organizational infrastructure of Ben Ali's RCD, but also its leading figures (Yardımc1-Geyikçi and Özlem 2018, 796).

This argument that the return of political figures from the former regime has led to the slowing down of the establishment of the institutional framework needed to protect human rights, or in some cases the cessation of the functioning of some already-established institutions, is mostly expressed by opposition political actors and civil society actors. For instance, Chafik Ayadi, a Popular Front MP, articulated how the human rights situation in the country has been negatively affected by the return of the Ben Ali era politicians with the following words:

A lot of faces from the dictatorship which were somehow responsible for limiting freedom of expression are coming back and there is an atmosphere of a lack of tolerance right now. ${ }^{20}$

The return of old faces from the Ben Ali era in the coalition of Nidaa Tounes' party was also seen by the civil society actors as the main reason for the change of the positions of Ennahda with regard to human rights protection in the country and readiness to support the necessary institutional framework for the protection of human rights. For instance, the vice president of Al-bawsala Selim Kharrat criticized Ennahda members for not being genuine in their support of human rights and using human rights as a tool to legitimise themselves.

During the period from 2011 to 2014, the Islamists ... used international human rights discourse to differentiate themselves from the Ben Ali era and to say they were the political party that would ensure, protect and promote human rights. However, we can observe that this discourse has shifted since the last elections in 2014 because Ennahda is now in a coalition with Nidaa Tounes, and Nidaa Tounes is like a newer version of Ben Ali. So Ennahda has changed its political discourse and their behaviour to be more in harmony with their new partner. ${ }^{21}$

Kharrat also pointed to the passivity of Ennahda's policy on the transitional justice process and on their alliance with Nidaa Tounes:

Ennahda was one of the main political parties to promote and help draft the law that made it possible to organically implement the transitional justice process but now, since the last elections, Nidaa Tounes has made a lot of cuts and weakened this process. Nidaa Tounes is the main political party that would be in danger due to the transitional justice process. So

20 Interview with Popular Front deputy Chafiq Ayadi conducted in November 2017.

21 Interview conducted with Selim Kharrat in November 2017. 
they are fighting with the institution (the Truth and Dignity Committee). Ennahda has said nothing to support this institution or to offer another opinion about the transitional justice process.

Recent reports also refer to numerous challenges in consolidating human rights protections in Tunisia, notably the failure to establish key institutions mandated by the constitution, such as the Constitutional Court, and the adoption of laws that threaten democratic transition, such as the administrative reconciliation law which grants amnesties to state officials accused of corruption (Human Rights Watch 2018). Freedom House, in its latest review of Tunisia, also refers to the influence of officials from the old regime as one of the main obstacles hindering full democratic transition. Tunisia's freedom rating also decreased from 1 to $2^{22}$ and suggested a downward trend, due to the growing pressures on the political system from powerful elements of the former regime and repeatedly postponed municipal elections (Freedom House 2018). As the UN Rapporteur Ahmed Shaheed states in his recent report, the tests that Tunisia faces include economic challenges, the need to establish key institutions mandated by the constitution such as the Constitutional Court, the existence of laws which violate constitutional standards, and the threats of violent extremism and terrorism (Shaheed 2018).

At the time of writing this article, the Constitutional Court anticipated in the 2014 Constitution, has still not been established, nor have its members been formally appointed. Ennahda deputy Ms Libadi outlined the situation and addressed the problem of coalition members' unwillingness to establish the institution in an interview conducted in February 2018 when she said the following:

We have voted for the law, we have set the criteria for choosing members and as a member of the Parliamentary Committee for Rights and Liberties I am simply angry: I am terribly angry and disappointed with the behaviour of the president of the assembly now. He is moving slowly as if he wants to prevent the establishment of the Constitutional Court. Yes, my party is in the coalition but I am not at all satisfied with the slow speed of establishing constitutional bodies, especially the Constitutional Court. In this year's opening session of the parliament the president of course once again committed himself to establishing the Constitutional Court this year. Honestly, if we fail to establish the Constitutional Court this year it will simply be a shame. Shame on Tunisian democracy. ${ }^{23}$

The Tunisian Parliament's March 2018 vote against a seven-month extension of the mandate of the Truth and Dignity Commission (IVD) deactivated a significant institution established after the uprisings, sending a strong signal that

22 Freedom Rating Explanation: $1=$ most free and $7=$ least free

23 Interview conducted with the Ennahda deputy Mahrezia Labidi in February 2018. 
transitional justice and human rights protections in Tunisia have slowed down. The IVD was created by the Transitional Justice Law in 2013 both to investigate human rights violations, covering the period from Tunisian independence in 1956 onwards, and to provide compensation and rehabilitation to victims. The law gave the IVD a four-year term with the possibility of a one-year extension. The vote against the extension of its mandate was not the first attempt to block the work of the IVD, with state institutions and officials attempting to hinder its progress from the start. Throughout its mandate period there was a lack of cooperation by government agencies including the Ministry of Interior, which refused to provide the IVD with access to secret police records, and the military justice system, which refused to transfer records of military trials related to human rights violations (Amnesty International 2018).

The president of the Women's Committee of the IVD Ibtihel Abdellatif complained about the lack of support by governmental institutions in fulfilling the Commission's mandate and said:

\begin{abstract}
Many female victims want to face their perpetrators. They want to be asked for forgiveness, they want an apology. However in Tunisia so far, the Ministry of the Interior has refused to allow apologies or to cooperate with us. Unfortunately this process of reconciliation is facing many difficulties. Many institutions do not cooperate with us. Today, for example, we held a workshop with the Ministry of Education about how to preserve the memories of human rights victims and how to educate children about human rights. However, no one [from the Ministry] came; the minister ordered them not to come. Only UN and IVD members were at the workshop. ${ }^{24}$
\end{abstract}

The parliamentary vote against the extension of the IVD's mandate was mainly supported by Nidaa Tounes members, including many political figures from the old regime, and it came just as the IVD had started referring cases of past human rights violations to criminal trial (Amnesty International 2018). Ennahda, which is particularly invested in the IVD's mandate as most victims are Ennahda members, declared the vote invalid due to procedural irregularities (Lynch 2018). After the vote Ennahda released a statement in which they underlined the importance of successfully completing the transitional justice process (Ennahda 2018), but at the same time they failed to defend the IVD as an institution. In reaction to and despite the parliamentary vote, the IVD declared that the extension of its mandate was not a parliamentary affair but its own, and they confirmed that they would nonetheless continue with their mandate until the end of year (Truth and Dignity Commission 2018).

24 Interview conducted with the President of the Women's Committee, Ibtihel Abdellatif in November 2017 


\section{Conclusion}

Tunisia is experiencing a relatively successful transition after the uprisings, which is not only because of national specificities, such as high literacy levels, a large middle class and strong civil society, but is mainly due to the fact that political actors were highly willing to make concessions to reach a consensus to protect human rights. The potential for secularist-Islamist polarisation of the country following the uprisings was masterfully controlled by Islamist and secular actors who promoted the transition process by reaching a consensus on controversial issues such as the place of religion in the constitution. Ennahda in particular made several concessions on controversial issues which were not actually in line with their previous ideological standpoint. The adoption of the 2014 Constitution, which is in line with international human rights standards, and the high level of freedoms and liberties provided after the uprisings positively contributed to the country's successful capacity building for the protection of human rights. In spite of the significant security, economic and legal challenges in the transitional Tunisia, the initial period after the uprisings witnessed a certain degree of interaction, and a willingness and capacity to protect human rights which also positively affected the transition process of the country.

The 2014 elections resulted in a grand coalition which has continued to seek a constant consensus in order to address the needs of transitional Tunisia. However, it has failed in addressing the ongoing economic growth problems and security threats. Moreover, the return of the old ruling elite to the political scene after the 2014 parliamentary elections gave rise to a decline in the capacity building. This in turn negatively impacted the human rights record of the country and also led to a decline in Ennahda's credibility, with regard to its willingness to protect and ensure human rights. In spite of the constructive steps taken to establish a stable institutional framework following the uprising, Tunisia today is still struggling with serious difficulties in making the established framework function due to a lack of both political will and adequate funding. The economic difficulties and security concerns are also restricting the ability of the government to establish the necessary legal and institutional framework for the protection of human rights. In some cases, even the government is enacting laws which harm the basic rights of Tunisian citizens. However, what is more worrying is a serious decline in the willingness of political actors to establish the institutions necessary for the effective protection of human rights as outlined in the constitution. 
Acknowledgment: Earlier drafts of this article were presented at the 2018 ISA Annual Convention and the BRISMES Annual Conference 2018. I would like to thank Mashood Baderin, Geoffrey Dancy, Christopher Fariss, Matt Gordner, Erin Collins, two anonymous reviewers, and the editorial team of Muslim World Journal of Human Rights for their helpful comments on earlier drafts of this article.

Funding: This project has received funding from the European Union's Horizon 2020 research and innovation programme under the Marie Sklodowska-Curie grant agreement No 703223.

\section{References}

Acemoglu, Daron, Camilo Garcia-Jimeno, and James A. Robinson. 2015. "The Role of State Capacity in Economic Development.” The Political Economist 11 (1): 7-9.

Al-Awadhi, Badria Abdullah. 2016. "Citizenship Rights in Selected Arab Constitution." Constitutionalism, Human Rights and Islam after the Arab Spring, edited by Rainer Grate, and Tilmann J Roeder, 559-77. Oxford: Oxford University Press.

Amnesty International. 2017. "Tunisia: Proposed bill could give security forces carte blanche to use unnecessary lethal force," https://www.amnesty.org/en/latest/news/2017/07/tunisiaproposed-bill-could-give-security-forces-cart e-blanche-to-use-unnecessary-lethal-force.

Amnesty International. 2018. "Public Statement.” Tunisia: Attempts to Obstruct Work of Truth and Dignity Commission undermine victims' rights and threaten transitional justice. MDE 30/8221/2018. https://www.amnesty.org/download/Documents/ MDE3082212018ENGLISH.pdf.

Anaya-Munoz, Alejandro, and Amanda Murdie. 2018. "The Will and the Way: How State Capacity and Willingness Jointly Affect Human Rights Improvement." paper presented at the ISA's 59th Annual Convention, April 4-7, 2018, San Francisco, CA.

Anderson, Lisa. 2011. "Demystifying the Arab Spring: Parsing the differences between Tunisia, Egypt and Libya." Foreign Affairs 90 (3): 2-7.

Andrieu, Kora. 2016. "Confronting the Dictatorial past in Tunisia: Human Rights and the Politics of Victimhoom in Transitional Justice Discourses since 2011." Human Rights Quarterly 38 (2): 261-93.

Baderin, Mashood. 2005. International Human Rights and Islamic Law. Oxford: Oxford University Press.

Bellin, Eva 2011. "Lessons from the Jasmine and Nile Revolutions: Possibilities of Political Transformation in the Middle East.” Middle East Brief, no. 50.

Bielefeldt, Heiner. 2000. ““Western” versus "Islamic” Human Rights Conceptions?: A Critique of Cultural Essentialism in the Discussion on Human Rights." Political Theory 28 (1): 90-121.

Borg, Stefan. 2017. "The Politics of Universal Rights Claiming: Secular and Sacred Rights Claiming in Post-Revolutionary Tunisia." Review of International Studies 43 (3): 453-74.

Chakroun, Hatem. 2018. "Tunisia: Human Rights Organisations and the State" Arab Reform Initiative. 
Chase, Anthony, and Amr Hamzawy. 2006. Human Rights in the Arab World. Philadelphia: University of Pennsylvania Press.

Dupret, Baudouin. 2016. "The Relationship between Constitutions, Politics and Islam. A Comparative Analysis of the North African Countries." Constitutionalism, Human Rights and Islam after the Arab Spring, edited by Rainer Grate, and Tilmann J. Roeder, 233-45. Oxford: Oxford University Press.

Elin, Zied 2013. “Infectious Revolution.” http://correspondents.org/en/2013/07/09/infectiousrevolution/

El-Khawas, A. Mohamed. 2012. "Tunisia's Jasmine Revolution: Causes and Impact." Mediterranean Quarterly 23 (4): 1-23.

El-Manai, Afifa. 2018. "Impact of Human Rights Movement in Tunisia between Legislation and Practice 2010-2016." Arab Reform Initiative.

Ennahda. 2018. "Statement: Ennahda Is Committed to the Transitional Justice as a National Milestone and a Basic Element of Democracy in Tunisia." www.ennahdha.tn/

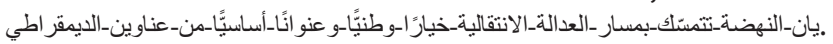

Entelis, P. John. 2007. "Republic of Tunisia." The Government and Politics of the Middle East and North Africa, edited by David E. Long, Bernard Reich, and Mark Gasiorowski, 516-48. Boulder: Westview Press.

Fassihian, Dokhi. 2018. "Democratic Backsliding in Tunisia: The Case for Renewed International Attention" Freedom House. Policy Brief.

Feuer, I Sarah 2016. "From Political Islam to Muslim Democracy. Tunisia’s Ennahda Changes Course." Foreign Policy.

Freedom House. 2013. “Freedom in the World 2013. Tunisia” http://www.freedomhouse.org/ report/freedom-world/2013/tunisia.

Freedom House. 2015. "Freedom in the World 2015. Tunisia." https://freedomhouse.org/report/ freedom-world/2015/tunisia.

Freedom House. 2018. “Freedom in the World 2018. Tunisia.” https://freedomhouse.org/ report/freedom-world/2018/tunisia.

Graenzer, Sieglinde. 1999. "Changing Discourse: Transnational Advocacy Networks in Tunisia and Morocco." The Power of Human Rights: International Norms and Domestic Change, edited by Thomas Risse, Stephen C. Ropp, and Kathryn Sikkink, 172-204. Cambridge: Cambridge University Press.

Guazzone, Laura. 2013. "Ennahda Islamists and the Test of Government in Tunisia." The International Spectator 48 (4): 30-50.

Hamd, Vida 2016. "Reflections on Human Rights Understandings in Light of the Arab Spring." The Hague Institute for Global Justice. Working paper 16.

Huellen van, Vera. 2013. "The Arab Spring and Spiral Model." The Persistent Power of Human Rights, edited by Thomas Risse, Stephen C. Ropp, and Kathryn Sikkink, 182-200. Cambridge: Cambridge University Press.

Human Rights Watch. 2015. “World Reports. Tunisia.” https://www.hrw.org/world-report/2015/ country-chapters/tunisia.

Human Rights Watch. 2016a. "World Reports. Tunisia." https://www.hrw.org/world-report/ 2016/country-chapters/tunisia.

Human Rights Watch. 2016b. "Dignity Debased. Forced Anal Examinations in Homosexuality Prosecutions." https://www.hrw.org/report/2016/07/12/dignity-debased/forced-analexaminations-homosexuality-prosecutions. 
Human Rights Watch. 2017. “World Reports. Tunisia.” https://www.hrw.org/world-report/2017/ country-chapters/tunisia.

Human Rights Watch. 2018. "World Reports. Tunisia.” https://www.hrw.org/world-report/2018/ country-chapters/tunisia.

Johnson, E. W. Darin. 2015. "Beyond Constituent Assemblies and Referenda: Assessing the Legitimacy of the Arab Spring Constitutions in Egypt and Tunisia." Wake Forest Law Review 50: $1007-56$.

Landman, Todd. 2005. Protecting Human Rights: A Comparative Study. Washington D. C.: Georgetown University Press.

Lynch, Marc 2018. "The First Casualty. DIWAN. Middle East Insights From Carnegie.” http://carnegie-mec.org/diwan/75827

Marks, L. Monika. 2014. “Convince, Coerce or Compromise? Ennahda's Approach to Tunisia's Constitution.” Brookings Doha Center Research Paper. Number 10.

Mayer Ann Alizebeth. 2013. Islam and human rights: tradition and politics. Boulder, Colo.: Westview Press.

Mednicoff, M Davif. 2003. "Think Locally -Act Globally? Cultural Framing and Human Rights Movements in Tunisia and Morocco." The International Journal of Human Rights 7 (3): 72-102.

Mokhtari, Shadi. 2015. "Human Rights and Power amid Protest and Change in the Arab World." Third World Quarterly 36 (6): 1207-21.

Monshipouri, Mahmood. 1998. Islamism, Secularism, and Human Rights in the Middle East. London: Lynee Rienner Publishers.

Monshipouri, Mahmood. 2014. Democratic Uprisings in the New Middle East. Youth, Technology, Human Rights, and US Foreign Policy. London: Paradigm Publishers.

Murphy, C. Emma. 2016. "The Fragility of Transition in Tunisia." North African Politics. Change and Continuity, edited by Zouibir H. Yahia, and White Gregory, 225-42. London: Routledge.

Netterstrom, L. Kasper. 2015. “The Islamists Compromise in Tunisia.” Journal of Democracy 26 (4): $110-124$.

Odysseos, Louiza, and Anna Selmeczi. 2015. "The Power of Human Rights/The Human Rights of Power: An Introduction.” Third World Quarterly 30 (6): 1033-40.

Pickard, Duncan. 2011. "Challenges to Legitimate Governance in post-revolutionTunisia." The Journal of North African Studies 16 (4): 637-52.

Pickard, Duncan. 2015. "Al-Nahda: Moderation and Compromise in Tunisia's Constitutional Bargain." Political and Constitutional Transitions in North Africa. Actors and Factors, edited by Justin O. Frosini, and Francesco Biagi, 4-33. London: Routledge.

Post, Lori Ann, Amber N. W. Raile, and Eric D. Rile. 2010. “Definin Political Will.” Politics and Policy 38 (4): 653-76.

Quamar, Muddassir. 2015. “Tunisia: Presidential and Parliamentary Elections, 2014.” Contemporary Review of the Middle East 2 (3): 269-88.

Rainer, Grote, and J. Roeder Tilmann. 2016. "The Constitutional Legacy of the Arab Spring." Constitutionalism, Human Rights and Islam after the Arab Spring, edited by Rainer Grate, and Tilmann J. Roeder, 907-19. Oxford: Oxford University Press.

Richardson-Little, Ned. 2015. "Human Rights as Myth and History: Between the Revolutions of 1989 and the Arab Spring." Journal of Contemporary Central and Eastern Europe 23 (2-3): 151-66.

Risse, Thomas. 2018. "Human Rights in Areas of Limited Statehood: From the Spiral Model to Localization and Translation." Human Rights Future, edited by Stephen Hopgood, Jack Snyder, and Leslie Vinjamuri, 135-59. Cambridge: Cambridge University Press. 
Sachedina, Abdulaziz. 2009. Islam and the Challenge of Human Rights. Oxford: Oxford University Press.

Sadek, George. 2013. The Role of Islamic Law in Tunisia's Constitution and Legislation PostArab Spring. The Law Library of Congress: Global Legal Research Center.

Sadek, George. 2013. The Role of Islamic Law in Tunisia's Constitution and Legislation PostArab Spring. Washington, DC: The Law Library of Congress: Global Legal Research Center. https://www.loc.gov/law/help/role-of-islamic-law/tunisia-constitution.pdf.

Shaheed, Ahmed. 2018. "Preliminary Findings of the Visit to Tunisia by the UN Special Rapporteur on Freedom of Religion or Belief.” 19 April 2018. http://www.ohchr.org/EN/ NewsEvents/Pages/DisplayNews.aspx?NewsID=22956\&LangID=E.

Stephens, J. Harrelson, and L. Rhonda Callaway. 2014. "You Say You Want a Revolution: The Arab Spring, Norm Diffusion, and the Human Rights Regime." Human Rights Review 15: 413-31.

Teyeb Mourad. 2014. Tunisia-Political Comeback of Ben Ali's Cohort a Setback to Democracy. African Argument. https://africanarguments.org/2014/11/18/tunisia-political-comebackof-ben-alis-cohort-a-setback-to-democracy-by-mourad-tayeb/.

Truth and Dignity Commission. 2018. "The Truth and Dignity Commission Press Conference on

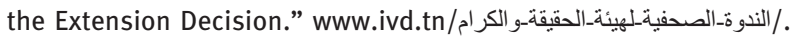

Willis, J. Michael. 2012. Politics and Power in the Maghreb. London: Horst \& Company. Yardımcı-Geyikçi, Şebnem, and Tür Özlem. 2018. "Rethinking the Tunisian Miracle: A Party Politics View." Democratization 25 (5): 787-803.

Yerkes, Sarah. 2018. "The Quiet Threat to Human Rights in Tunisia.” Foreign Affairs. 